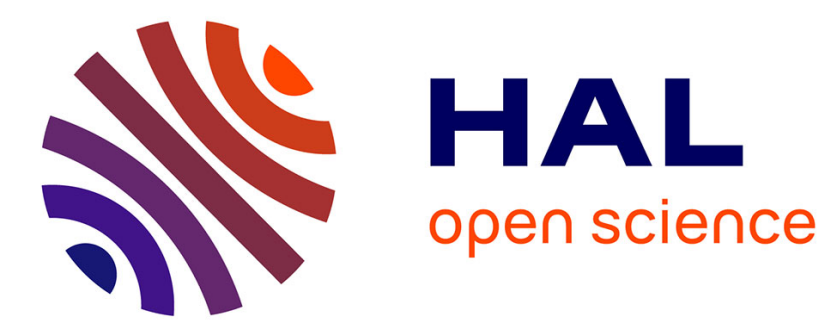

\title{
Investment in ICTs: an empirical analysis
}

Gilbert Cette, Jimmy Lopez, Pierre-Alexandre Noual

\section{To cite this version:}

Gilbert Cette, Jimmy Lopez, Pierre-Alexandre Noual. Investment in ICTs: an empirical analysis. Applied Economics Letters, 2005, 12, 10.1080/13504850500042280 . hal-01247384

\section{HAL Id: hal-01247384 \\ https://hal.science/hal-01247384}

Submitted on 22 Dec 2015

HAL is a multi-disciplinary open access archive for the deposit and dissemination of scientific research documents, whether they are published or not. The documents may come from teaching and research institutions in France or abroad, or from public or private research centers.
L'archive ouverte pluridisciplinaire HAL, est destinée au dépôt et à la diffusion de documents scientifiques de niveau recherche, publiés ou non, émanant des établissements d'enseignement et de recherche français ou étrangers, des laboratoires publics ou privés. 


\section{Investment in ICTs: an empirical analysis}

Gilbert Cette, Jimmy Lopez et Pierre Alexandre Noual

This paper addresses the question of whether differences in the price elasticity of demand for Information and Communication Technologies (ICTs) could explain why Europe lags behind the USA in terms of ICT diffusion. Annual macroeconomic data covering the period 1975-2001 is used and five countries considered: France, Germany, the Netherlands, the UK and the USA. Europe's lag in ICT diffusion does not appear to be linked to cross-country differences in the price elasticity of demand for ICT products. The results suggest that at least part of the gap in ICT diffusion should be ascribed to more structural cross-country differences. The estimated value of the price-elasticity of computer hardware and software is generally lower than 1 which, given the decline in the relative price of these products, explains the increase in their share of investment expenditure and GDP. This situation is characteristic of a diffusion stage and is necessarily temporary.

JEL classification: E22, O47, O57, R24.

I. Introduction

In recent years, a large body of literature has been devoted to ICTs and to the impact of ICT production and use on productivity (sees for example the Oliner and Sichel, 2002; Jorgenson, 2003 or OECD's report, 2003). Most of these analyses estimate the impact to be considerable. They also highlight sizeable differences across industrialized countries in the diffusion of ICT. The USA stands out as the country where the diffusion of ICT is the broadest.

Various suggestions have been put forward to explain the European lag. The diffusion lag probably stems partly from the fact that the ICT-producing sector is relatively larger in the USA and that these technologies can therefore begin to spread earlier. Gust and Marquez (2004) put forward three explanations for the European ICT diffusion lag: complementarity of ICT use with skills; burdensome or unstable regulations on goods and labour markets, preventing companies from restructuring work practices; oligopolistic settings raising access cost and lowering Internet use. These explanations are still awaiting robust statistical confirmation.

This paper examines another possible explanation, that of lower price elasticity of demand for ICT (in absolute terms). If the price elasticity were lower, then the continuous steep decline in the relative price of ICTs over the last few decades would have resulted in a smaller increase in the diffusion of 
these technologies. Here, the analysis of Cette and Noual (2003) is built on. Annual macroeconomic data covering the period 1975-2001 is used and five countries considered: France, Germany, the Netherlands, the UK and the USA. National accounting data rely on conventions that differ across countries (cf. Cette et al., 2000) and so cannot be used directly for this comparative study. The sources and construction of the data are the same as in Cette and Noual (2003), using the Van Ark et al. (2002a) database which greatly reduces methodological differences. ${ }^{1}$ The price series is calculated assuming that in each country, the price of each input relative to the GDP deflator is the same as in the USA.

After comparing ICT diffusion throughout the production systems of the different countries (Section II), a factor demand model is proposed in Section III and the results of its estimation are analyzed in Section IV.

\section{ICT Diffusion Across Countries}

Earlier studies, including $\operatorname{OECD}(2002,2003)$ or Van Ark et al. $(2002 a, b)$, show a stable ranking in terms of nominal ICT investment rates and that the USA have a clear lead. ICT investment rates rose at least twofold in all of the countries between 1980 and 2000. The country rankings obtained for the nominal ICT capital output ratio is similar to that found for the investment rate (see Fig. 1). These findings strengthen the case for modeling ICT capital demand in a bid to explain the diffusion differentials.

III. The Model

The estimated model is static and corresponds to a long-term relationship. ${ }^{2}$ Seven inputs are identified: labour plus six components of capital, namely computer hardware, software, communication equipment, transport equipment, other equipment and structures. The full model justifying the following regression equation is available from the authors upon request: starting from constant returns to scale production function, the predicted factor demand for each input is obtained, and this equation augmented to take various measurement problems into account. In the end the following is obtained:

$$
\begin{gathered}
f_{j, k}-q_{k}=-a 1_{j, k} \cdot\left(c_{j, k}-p_{q, k}\right)+a 2_{T, k}+a 3_{j, k} \cdot A G E_{j, k} \\
+a 4_{j, k} \cdot c h g_{k}+a 5_{j} \cdot p_{h w, k}+a 6_{j, k}+a 7_{k}+u_{j, k}
\end{gathered}
$$

\footnotetext{
${ }^{1}$ For more information, see Appendix 1 of Cette and Noual (2003).

${ }^{2}$ Cette and Noual (2003) propose a number of short-term estimation adjustments corresponding to an error correction model. These yield weak results because of the short time dimension of the data.
} 
In this relation, for each country $k$, the logarithm of the capital output ratio of input $j, f_{j, k}-q_{k}$, depends on: (i) the log of the relative price of input $j$ as compared to all inputs, $c_{j, k}-p_{q, k}$; (ii) Total Factor Productivity effects denoted by annual constants $a 2_{T, k}$; (iii) mismeasurement correction variables, i.e. average age of equipment for input $j, A G E_{j, k}$, the log of the exchange rate $c h g_{k}$, the log of the computer hardware price $p_{h w, k}$, country/product dummies $a 6_{j, k}$; (iv) country dummies $a 7_{k}$. For software and communication equipment, $A G E_{j, k}$ is used to adjust for cumulated measurement errors in the price of investment in each country. The price of hardware also serves to adjust for a potentially insufficient incorporation of quality improvements in the price series for those two factors. Finally, the exchange rate captures idiosyncracies in the relative price of each country, as well as direct terms of trade effects for ICT importers.

Also various simplifying hypotheses are used to estimate simplified forms of this relation:

H1 The exchange rate, equipment age and computer hardware prices are removed from the list of independent variables: $a 3_{j, k}=a 4_{j, k}=a 5_{j, k}=0$.

H2 The effects of autonomous technical progress follow purely trend-based country-specific movements: $\gamma_{T, k}=\gamma_{k} . T$ and $a 2_{T, k}=a 2_{k} . T$.

H3 The product/country constants are removed from the list of independent variables, except in the case of the labour input: $a 6_{j, k}=0 \forall j, k$ if $j \neq t r$.

H4 The cost elasticity of factor demand is identical in all countries: $a 1_{j}, k=a 1_{j} \forall k$.

The equation is estimated for each country over the period 1975-2001 using pooled data for all seven inputs, i.e. 189 observations in all ( 27 years $\times 7$ products). Under hypothesis $H 4$, the relation is also estimated simultaneously for the five countries, i.e. 945 observations ( 27 years $x 7$ products $x 5$ countries).

IV. The Results

The OLS estimations are performed by stacking the data on the time/product dimensions or, under hypothesis $\mathrm{H} 4$, on the time/product/country dimensions. Concerning the tests under hypotheses $\mathrm{H} 1$ to $\mathrm{H} 4$, it appears that (Table 1 ):

- Hypothesis $\mathrm{H} 1$ is rejected for all countries except the USA. This supports the inclusion of various variables to adjust for measurement problems;

- Hypothesis H2 is rejected for France and the UK, but accepted for the other three countries; 
- Hypothesis H3 is rejected for all countries;

- Hypothesis $\mathrm{H} 4$ is validated for all three ICT products.

In view of these results, the comments are focused on the estimates obtained under hypotheses $\mathrm{H} 2$ and $\mathrm{H} 4$ simultaneously. The coefficients for the exchange rate, age and the country/product constants combine multiple effects and their sign is indeterminate; their estimated values are neither shown nor commented here. The main lessons that can be drawn from the estimations are that (Table 2):

- Estimated cost elasticities are generally significant and have the expected negative sign;

- Demand for computer hardware and software is highly sensitive to price. There estimated price elasticity are even generally lower than -1 ;

- These results appear to be robust to hypothesis $\mathrm{H} 2$.

To assess robustness, the model was estimated over different periods and without the labour input; estimated elasticities were very similar. The measurement errors problem prompted estimations to be carried out using the instrumental variables (IV) method, but it was not possible to find acceptable instruments. This does not mean that no list of instruments can be found, but if the measurement errors are certainly sizeable for some variables, the white noise component of these errors is doubtless fairly small.

\section{Conclusion}

The European lag in ICT diffusion does not appear to result from cross-country disparities in the price elasticity of demand for different ICT products. The analysis suggests that, because of the rejection of hypothesis $\mathrm{H3}$, the differential in ICT diffusion is partly rooted in more structural cross-country differences. The estimated value for the price elasticity of computer hardware and software is generally lower than -1 , which, given the decline in the relative price of these products, explains the increase in their share of overall capital expenditure and GDP. This situation is characteristic of a diffusion stage and is necessarily temporary. 
Table 1. Tests of hypotheses $\mathrm{H} 1$ to H4: Fisher tests -

Probability of wrongly rejecting the tested hypothesis

\section{A - Tests of hypotheses $\mathrm{H} 1, \mathrm{H} 2$ and $\mathrm{H} 3$}

\begin{tabular}{|l|l|c|c|c|c|}
\hline \multicolumn{2}{|c|}{} & H1 tests & H2 tests & H3 tests & Under H2 \\
\hline \multirow{4}{*}{$\begin{array}{l}\text { For each } \\
\text { country }\end{array}$} & France & 0 & 0.009 & 0 & 0 \\
\cline { 2 - 6 } individually & Germany & 0 & 0.179 & 0 & 0.079 \\
\cline { 2 - 6 } & Netherlands & 0 & 0.288 & 0.03 & 0.428 \\
\cline { 2 - 6 } & UK & 0 & 0.037 & 0 & 0 \\
\cline { 2 - 6 } & USA & 0.445 & 0.556 & 0 & 0 \\
\hline \multicolumn{2}{|l}{ Under hypothesis H4 } & 0 & 0.049 & 0 & 0 \\
\hline
\end{tabular}

The probability of wrongly rejecting hypothesis $\mathrm{H} 1$ is 0.445 for the USA and 0 for all other countries. Accordingly, hypothesis $\mathrm{H} 1$ appears to be acceptable for the USA.

\section{B - Tests of hypothesis $\mathrm{H} 4$}

\begin{tabular}{|l|c|c|c|}
\hline Input & $\begin{array}{c}\text { Excluding other } \\
\text { hypothesis }\end{array}$ & Under hypothesis H2 & $\begin{array}{c}\text { Under hypothesis H2 } \\
\text { and H3 }\end{array}$ \\
\hline Computer Hardware & 0.235 & 0.275 & 0.055 \\
\hline Software & 0.533 & 0.096 & 0.093 \\
\hline Communication equipment & 0.499 & 0.748 & 0.960 \\
\hline Other equipment & 0 & 0.209 & 0.007 \\
\hline Transport equipment & 0.038 & 0.327 & 0.059 \\
\hline Structures & 0.236 & 0.773 & 0 \\
\hline Labour & 0.044 & 0.505 & 0.987 \\
\hline
\end{tabular}

Table 2. Estimates of the price elasticity of factor demand: results for coefficient $a \mathbf{1}_{j, k}$ of the estimated relation

\begin{tabular}{|l|c|c|}
\hline Input & Under hypothesis H4 & Under hypothesis H2 and H4 \\
\hline \multirow{2}{*}{ Computer hardware } & -1.25 & -1.27 \\
& $(-63.6)$ & $(-62.9)$ \\
\hline \multirow{2}{*}{ Software } & -1.98 & -1.74 \\
& $(-15.4)$ & $(-14.1)$ \\
\hline \multirow{2}{*}{ Communication equipment } & -0.38 & -0.07 \\
& $(-3.0)$ & $(-0.6)$ \\
\hline \multirow{2}{*}{ Other equipment } & -0.46 & -0.14 \\
& $(-6.4)$ & $(-2.1)$ \\
\hline \multirow{2}{*}{ Transport equipment } & -0.60 & -0.12 \\
& $(-4.8)$ & $(-1.1)$ \\
\hline \multirow{2}{*}{ Structures } & -0.12 & 0.06 \\
& $(-3.2)$ & $(1.6)$ \\
\hline \multirow{2}{*}{ Labour } & -2.03 & -1.74 \\
& $(-10.2)$ & $(-9.5)$ \\
\hline $\mathrm{R}^{2}$ & 0.998 & 0.997 \\
\hline
\end{tabular}

Notes: Estimation period: 1975-2001 - Annual data - OLS method.

Estimations are carried out for all countries by stacking the data for different products-countries.

The numbers in parentheses correspond to the values for student's t-statistic. For the sake of place and clarity, the above table shows the estimates for price elasticities only. 
Fig. 1. ICT capital output ratio - ICT capital stock over GDP in nominal terms and \%

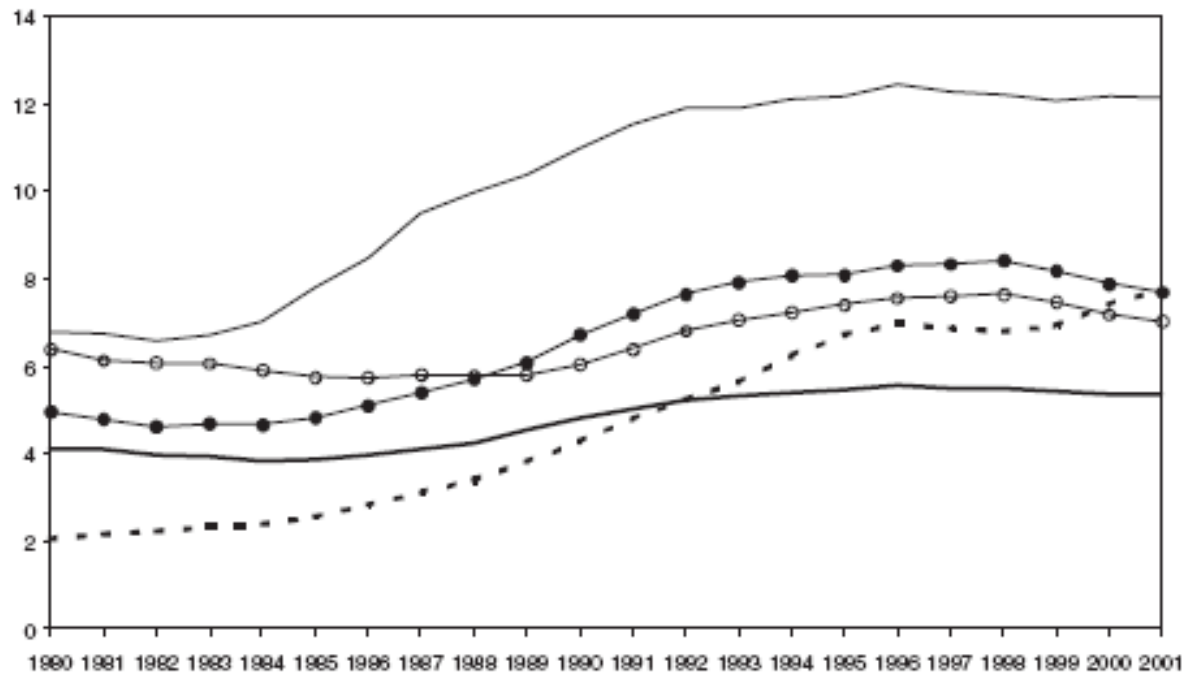

(-) France, (-•-) Germany, (- -) UK, (-o-) Netherlands, (-) USA

Source: authors calculations from basic data supplied by Van Art et al. (2002a) 